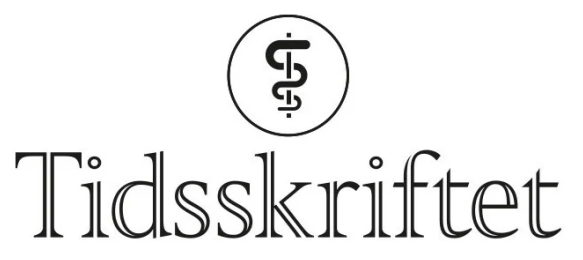

DEN NORSKE LEGEFORENING

\title{
Samtykke og forskning på covid-19
}

\author{
KOMMENTAR
}

\section{JACOB C. HØLEN}

jacob.holen@medisin.uio.no Jacob C. Hølen er sekretariatsleder ved Regional komite for medisinsk og helsefaglig forskningsetikk sør-øst.

Forfatteren har ikke oppgitt noen interessekonflikter.

Forskning på Covid-19 er svært viktig for hele samfunnet og en forutsetning for å kunne bekjempe pandemien. De Regionale komiteer for medisinsk og helsefaglig forskningsetikk (REK) har innført hastebehandling av slike prosjekter (1).

Hastebehandlingen er mulig fordi både sekretariat og komité har mobilisert, men den foregår fortsatt innenfor forsvarlige rammer. Historien bør ha lært oss at det nettopp er i krisetider at risikoen $\emptyset \mathrm{ker}$ for at samfunnets kortsiktige interesser kan overstyre menneskerettighetene og våre grunnverdier. Samtykke er en slik grunnverdi, og det er all grunn til at det fortsatt skal være hovedregel, selv om samfunnet nå er i en krise.

REK har hjemmel til å tilgjengeliggjøre data som normalt samles inn i helsetjenesten, til forskning uten samtykke. Det vil også kunne være aktuelt for forskning på covid-19, og det vil svare ut noe av forfatternes ønsker. Vi har også sett eksempler på intensivforskning der man kan benytte utsatt samtykke. Da kan helsepersonell/forsker samle inn data, etter godkjenning fra REK, og spørre om samtykke til å bruke disse når pasienten igjen blir samtykkekompetent. Hvis pasienten dør, vil man kunne spørre pårørende i ettertid. Får forsker samtykke kan det forskes, hvis ikke må data slettes. Utsatt samtykke vil være aktuelt for denne situasjonen, ikke minst fordi pårørende kanskje ikke er tilstede på grunn av smittevernstiltak.

REK mottar mange og gode søknader om covid-forskning. Det pågår en viktig forskningsdugnad der helsepersonell, forskere, pasienter og forvaltning bidrar på en måte som bør gjøre oss stolte. Skal denne forskningen også gjøre oss stolte i ettertid, er det i alles interesse at den ble gjennomført forsvarlig.

Dette innlegget er ikke diskutert med hele REK og må leses som forfatterens egne synspunkter.

\section{LITTERATUR}

1. Regionale komiteer for forskning og medisinskfaglig etikk. Aktuelle meldinger. https://rekportalen.no/ Lest 16.3.2020. 
Publisert: 4. mai 2020. Tidsskr Nor Legeforen. DOI: 10.4045/tidsskr.20.0293

(C) Tidsskrift for Den norske legeforening 2023. Lastet ned fra tidsskriftet.no 26. april 2023. 